\title{
LEAVES OF GRASS AS A "WOMAN'S BOOK"
}

\section{Maire Mullins}

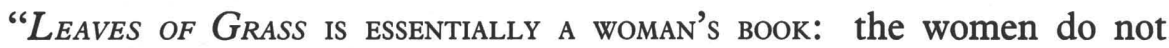
know it, but every now and then a woman shows that she knows it: it speaks out the necessities, its cry is the cry of the right and wrong of the woman sex-of the woman first of all, of the facts of creation first of all-of the feminine: speaks out loud: warns, encourages, persuades, points the way." Walt Whitman made this remark to Horace Traubel in the late summer of 1888 , thirty-three years after the first edition of Leaves of Grass was published. This seems a curious statement, especially since Leaves of Grass has, with very few exceptions, been read primarily as expressive of male sexuality and desire. An overview of critical studies of Whitman's work reveals that the poems have been read for the most part with an emphasis upon masculine sexuality: phallic imagery, so evident throughout Leaves of Grass, homosexuality as expressed in the Calamus cluster and elsewhere, the lyric erotic passages in "Song of Myself." At first glance, this focus seems warranted, for these themes and issues are central in Whitman's verse. Nor have the qualities of receptivity, expansiveness, and connection gone unnoticed in Leaves of Grass; however, in some instances they can be understood as stemming from the kind of writing which Hélène Cixous and other French feminist writers describe.

In many places throughout Leaves of Grass, Whitman refers to an equable, democratic treatment of gender. He writes, for instance, "I am the poet of the woman the same as the man, / And I say it is as great to be a woman as to be a man." ${ }^{\text {"3 }}$ If this is so, if Whitman is the poet of the woman as well as of the man as he claims to be, then women's sexuality and voice in Leaves certainly call for a more developed critical consideration. In general, Whitman's portrayal of women and women's sexuality in Leaves of Grass has generated several critical approaches; one approach is to acknowledge (and sometimes, lament) Whitman's perceived reduction of women to types, and to examine these types as indicative of negative or positive societal values (for instance, the prostitute or the mother). ${ }^{4}$ Another approach is to point out the inconsistency of Whitman's attitudes about women, his assertion of democratic equality versus the depiction of women in his verse. These critical approaches to women in Leaves of Grass (and, certainly, these categories are neither mutually exclusive nor exhaustive) are due, to some extent, 
to the larger problematic of the expression/repression of women's sexuality in nineteenth-century America; Whitman can be taken to task for some of the restrictive stereotypes in his verse, but it should also be noted that these constrictive images are, to some degree, reflective of societal mores as well.

Whitman's rendering of women's body and women's desire, especially his treatment of women's eroticism, has been relatively overlooked. Leaves can be read as a "woman's book," but this must be done from a different critical perspective than has thus far been taken in regard to the poems. The reading strategies Hélène Cixous has developed, particularly her ideas about l'écriture féminine (writing-the-body), allow for a more nuanced recognition of those places in the Leaves where a distinctly féminine eroticism is called forth. ${ }^{5}$ In her work, Cixous emphasizes multiplicity, diffuseness, and openness-experienced through the body and in particular through orgasmic utterance-as essential characteristics of féminine writing. ${ }^{6}$ The connection between the plurality of being and sexual desire, once articulated, contributes to a concept of the subject which is fluid, multiple, even contradictory. The kinds of writing Cixous describes can be found in many places in Leaves of Grass. In this essay, I discuss passages from three of Whitman's poems as exemplary instances of l'écriture féminine: "Crossing Brooklyn Ferry," section eleven of "Song of Myself," and the woman's dream sequence from "The Sleepers."

The term often used to describe the way in which Whitman infuses the external world with spiritual significance is "cosmic consciousness." As Karl Shapiro notes, cosmic consciousness may be defined as "a sense of identification with the universe, an intellectual enlightenment or illumination which may last only briefly but which ... places the individual on a new plane of existence." In many instances, however, cosmic consciousness does not adequately describe the body consciousness Whitman incorporates in Leaves. "Cosmic consciousness" emphasizes intellect, thus creating a set of binary oppositions. In this hierarchical relationship the body, so crucial in Leaves of Grass, is elided, forgotten. The féminine consciousness which Cixous writes of calls for a recognition of repressed sexual drives and their connections to language. Féminine writing emphasizes an alogical way of knowing which allows for the outpouring of uninhibited pleasure. ${ }^{8}$ This knowledge is sometimes voiced in Whitman's verse as well.

Both Whitman and Cixous describe a relation with the world that does not prioritize the unitary self: in their work, the self is multiplicitous, slippery, shape-shifting. This relation, according to Cixous, is "the relation one can have with the other and with the world when one has 'deheroized' oneself by not forgetting the other; even if it is a cockroach, or even if it is the rain, then one has the type of love that the 
rain and the earth have one for the other." Cixous writes of a "cockroach" and the rain; Whitman, of flood-tides, clouds, and blades of grass. Implicit in the "type of love" Cixous describes and Whitman incorporates in Leaves of Grass is a natural, unremarkable dependence that does not detract from the relationship but that nurtures it. Whitman "deheroizes" himself in many poems, particularly "Crossing Brooklyn Ferry," section eleven of "Song of Myself," and the woman's dream section of "The Sleepers." This deheroization is perhaps surprising, for Whitman is often viewed as an unabashedly self-celebratory poet. Yet this contradiction - as Whitman's contradictions tend to donot only endears Whitman to the reader, it renders his verse accessible, elastic, and unpredictable. "By not forgetting the other" Whitman crosses over into the present moment of the reader and the reading experience.

In "Crossing Brooklyn Ferry" the speaker's vatic identification with those to come is attained through sensory immersion, through an attentiveness to detail, and through a celebration of this moment. ${ }^{10}$ In her work, Cixous describes sensory immersion in a general way as "an endless circulation of desire from one body to another, above and across sexual difference . . . a detachment, a kind of disengagement, not the detachment that is immediately taken back, but a real capacity to lose hold and let go." 11 Through an aware detachment, an unmediated sense of the body becomes part of the experience Whitman writes of in this ferry crossing. Time, the ferry, the course of the sun-all moving quickly - are caught in the speaker's gaze:

Flood-tide below me! I see you face to face!

Clouds of the west-sun there half an hour high-I see you also face to face. (1-2)

Cixous also speaks of "wandering, excess, risk of the unreckonable"all characteristics of a féminine text, which is anti-teleological, negating and undermining any sense of closure, and non-linear. These qualities are indicative of Whitman's verse and method, particularly excess: lines which sweep across and down the page, catalogs wide open in scope, and expansive descriptive detail. Whitman's contemporaries often found his poems "disturbing" because of the ways in which he enfolds a bodily perspective into language. Cixous's ideas about language provide readers with multiple perspectives into Leaves of Grass, allowing them to read from more than one point of view. Whitman's verse often demands this shaking-free from fixity and complacency.

Drawing life and sustenance from the landscape that unfolds around him, the speaker of "Crossing Brooklyn Ferry" gives this sustenance back to others through a recognition of a relation that collapses false categories of identity and time. Rather than separating the reader from the speaker, these gaps are bridged through the text and through 
this plural, open-ended experience. The speaker circulates freely, opening to others as well as to inanimate objects-all become part of this experience without loss of difference. In his Notebooks, Whitman writes, "I know well enough the perpetual myself in my poems, but it is because the universe is in my self-it shall all pass through me as a procession.-I say nothing of myself, which I do not equally say of all others, men and women." 12 Whitman's multiple identity is the universe which is in the self, and is not univocal. The poem shares with the reader a sense of attentiveness and receptivity not only to this particular crossing, but to all crossings. "What is it then between us?" the speaker asks, "What is the count of the scores or hundreds of years between us?" (54-55).

In the latter sections of "Crossing Brooklyn Ferry," the speaker reaches a greater level of intimacy with the reader/other through a series of rhetorical questions which decenter the text by refusing to locate an authoritative statement in a knowing "I." "Who was to know," Whitman writes, "what should come home to me? / Who knows but I am enjoying this? / Who knows, for all the distance, but I am as good as looking at you now, for all you cannot see me?" (89-91). In some ways, the speaker displaces his own homoerotic desire into this relation with the reader, an erotic relation which calls for a way of knowing akin to that which Cixous describes in her essay "Extreme fidelity":

One of the first lessons about living is the one about knowing how not to know, which does not mean not knowing, but knowing how not to know, knowing how to avoid getting closed in by knowledge, knowing more and less than one knows, knowing how not to undertand, while never being on the side of ignorance. It is not a question of not having understood anything, but of not letting oneself get locked into comprehension. Each time that we come to know something, in reality it is a step. Then we have to strike out for the un-known, to make our way along in the dark, with 'an apple in our hand' like a candle. ${ }^{13}$

Through the rhetorical strategy of questions, Whitman's féminine text avoids closure and prompts the reader to proceed "in the dark" by avoiding the fixity and closure of knowing. Now new insight and enlightenment are possible, and this new knowledge reaches its culmination in a moment of simultaneous possession: "What is more subtle than this which ties me to the woman or man that looks in my face? / Which fuses me into you now, and pours my meaning into you?" (96-97). This possession is not passivity on the part of the "woman or man that looks in my face"; it signifies the moment of deheroization. The other is not forgotten; the other is included as part of the exchange. Bound to the river, bound to the "flood-tide" and "scallop-edg'd waves," and bound to the reader, the speaker of "Crossing Brooklyn Ferry" expresses, in Cixous's words, this "type of love that the rain and 
the earth have one for the other" ("Reaching the Point of Wheat," 19). Whitman writes:

We understand then do we not?

What I promis'd without mentioning it, have you not accepted?

What the study could not teach - what the preaching could not accomplish is accomplish'd, is it not? (98-100)

The "you" of Leaves of Grass represents the camarados, the lovers, with whom Whitman exchanged glances, and the readers of the present and future. Kerry Larson points out that the "relationship between author and reader is not something Whitman works from but works toward. Precisely what most poetry takes for granted Whitman takes as his explicit subject." 14 Later, Whitman described what he thought of as the enabling quality of his writing: "I round and finish little, if anything, and could not, consistently with my scheme. The reader will always have his or her part to do, just as much as I have had mine. I seek less to state or display any theme or thought, and more to bring you, reader into the atmosphere of the theme or thought-there to pursue your own flight." ${ }^{15}$ Poetry reading, like poetry writing, requires exertion as well as a creative imagination, Whitman reminds us. The reading of "Crossing Brooklyn Ferry," and of many other poems in Leaves, becomes a collaborative activity that connects the long-dead poet with the breathing reader in a startling manner.

For Whitman, as for Cixous, writing becomes a passageway to other selves, other bodies, other desires. Cixous describes this multifarious experience in the following way:

Writing is the passageway, the entrance, the exit, the dwelling place of the other in me-the other that I am and am not, that I don't know how to be, but that I feel passing, that makes me live-that tears me apart, disturbs me, changes me, who? - a feminine one, a masculine one, some? - several, some unknown, which is indeed what gives me the desire to know and from which all life soars. ${ }^{16}$

"The other that I am and am not" comes into consciousness through the writing itself, and, in Whitman's poetry, through the participatory reading process. To some degree, "Crossing Brooklyn Ferry" is about the difficulty of naming the unnameable, the unmentionable, the forbidden: the desire for the same sex. Rather than simply write about the body, Whitman infuses the connection between the plurality of being and sexual desire directly into the verse, thus creating the body/textual consciousness which Cixous describes.

Section eleven of "Song of Myself" has inspired numerous critical readings, but its evocative richness in terms of women's sexuality and eroticism has been relatively overlooked. ${ }^{17}$ These lines follow a description of a runaway slave in section ten. The slave rests and recuperates, 
and is helped along on the arduous journey to freedom. This literal enactment of the struggle for freedom serves as a precursor to the dramatic awakening in the following passage. Like the woman whose dream Whitman enters into and articulates in "The Sleepers," the woman in section eleven is anonymous, intimate to the reader only in the intimacy of her desires and pleasures. This anonymity has led many critics to speculate about the woman's marital status. Many critics label her a "spinster," yet Whitman gives the reader no indication that the woman is either married or unmarried. We know only that she is "lonely,"-and loneliness was not restricted to the unmarried segment of the population in nineteenth-century America. At first the joy of the young men splashing and bathing in the water near her home appears to underscore her loneliness: "Twenty-eight young men bathe by the shore, / Twenty-eight young men and all so friendly; / Twenty-eight years of womanly life and all so lonesome" (199-201). Even their number, twenty-eight, serves as a reminder of her situation because it echoes her age and emphasizes her singleness in contrast to the group's spontaneity and community. Her gender separates her from the men; alone, the young woman looks out upon them, so comfortable and familiar with each other, so unaware of her glance.

By giving over to her fantasy and to her erotic impulses, the woman metaphorically sheds the bonds of convention and inhibition. The window from which she looks serves as a transparent shield, for it at once permits and denies access to interior and exterior regions: "She owns the fine house by the rise of the bank / She hides handsome and richly drest aft the blinds of the window" (202-203). The house belongs to the woman, which implies economic independence, just as the rich dress implies social status. She is "richly drest," covered, cloaked doubly by the house and her apparel, and protected by the "blinds of the window." She "hides"- does not want to be seen, but wants to look out, to be among them, to be with them, without their knowing her desire. The young woman becomes part of the young men's world; as she blends in among them, no one in particular is mentioned, for even "the homeliest of them is beautiful to her" (205). The sight of these glistening bodies gradually transforms her; entering the water, even if only vicariously, enables the woman to open herself to an erotic and liberating sexual moment of union and contact. "Woman must put herself into the text-as into the world and into history-by her own movement," Cixous writes ("Medusa," 875). In Whitman's poem, the young woman's figurative movement out of her house leads to a daringly transgressive act: her hand passes over the bodies of the young men, and descends "tremblingly from their temples and ribs" (212-213). Cixous describes women's autoerotic fantasies as silenced, repressed, and calls for the writing-out of these desires: "I have been amazed more than 
once by a description a woman gave me of a world all her own which she had been secretly haunting since early childhood. A world of searching, the elaboration of a knowledge, passionate and precise interrogation of her erotogeneity. . . . Beauty will no longer be forbidden" ("Medusa," 876). Whitman writes out woman's autoerotic desire in this passage: the young woman's explicitly physical action binds her to the young men, whose uninhibited happiness gladdens and inspires her. The only one aware of her figurative movement out of enclosure and isolation is the poem's speaker, who watches her watching them and voices her emotions. The poem is thus comprised of a complex series of "looks": the young men who delight in each other, the young woman who delights in the young men, and the poem's speaker who partakes in both the young woman's gaze and her desire.

The speaker becomes both young woman and young men, the one who loves and the ones who are loved, attaining what Cixous terms "vatic sexuality": a doubly-sexed vision which "doesn't annul differences but stirs them up, pursues them, increases their number" ("Medusa," 884). Whitman "stirs up" these differences through paradox and pronoun usage; "she" is clearly the woman behind the window whom the "I," the speaker of "Song of Myself," carefully observes. This "doubly-sexed vision" not only notes the woman's desire, but merges with it. The forbidden suddenly becomes the possible through the vatic insight of the "I" who watches and takes note: "Where are you off to, lady? for I see you, / You splash in the water there, yet stay stock still in your room" (206). Writing of the possibilities for the expression of this "vatic bisexuality," Cixous notes that in this kind of exchange "what takes place is an endless circulation of desire from one body to another, above and across sexual difference" "Castration," 53). The "circulation of desire from one body to another" takes place between the woman and the speaker / "I" who senses her desire. Just as the young men "do not know" who "seizes fast to them," the young woman does not realize that the speaker / "I" "seizes fast" not to her body, but to her desire, "making it fly" in language. In section eleven the speaker (earlier figured as a male, and in many passages of Song of Myself as Whitman himself) cuts "above and across sexual difference" as he extends into the other, expressing the pleasure of the "twenty-ninth bather" as well as his own repressed homoerotic pleasure:

The beards of the young men glisten'd with wet, it ran from their long hair, Little streams pass'd all over their bodies,

An unseen hand also pass'd over their bodies,

It descended tremblingly from their temples and ribs. (210-213)

The joy and playfulness of the young men inspire and delight the young woman, and the speaker writes out her pleasure and his own as she/he 
goes among them, touches them, and makes love to them, voicing the expanded desire of the féminine consciousness.

Through the woman Whitman releases the "pent-up aching rivers" of the repressed féminine self as she/he mingles, "dancing and laughing" (208), among the bathers, who do "not see her," and "do not ask who seizes fast to them" (214). In this passage, muted and repressed pleasures are articulated. From the silent, dark womb of her house the woman emerges; initially marginalized and excluded, the young woman gives voice to her emotions through her fantasy. As she joins the twenty-eight young men, the monologue of her life is transformed into a thousand songs, a thousand dances. She rediscovers others and herself through reclamation and reaffirmation of the body/bodies: "The young men float on their backs, their white bellies bulge to the sun, they do not ask who seizes fast to them, / They do not know who puffs and declines with pendant and bending arch / They do not think whom they souse with spray" (214-216). The writing of her desire expands into an erotic act as the bathers, the woman, and the speaker abandon the "know" and "think" of conventional expression and instead reach jouissance, with its open-ended, orgasmic implications. ${ }^{18}$ Fouissance is the term many French feminist critics and writers use to refer to the liberation of silenced desire in physical, emotional, and spiritual ways. In this instance, the woman, initially aloof, comes to embrace lyrical erotic pleasure in a moment of spontaneous joy. She gives herself without expectation of return, and her pleasure and delight circulate among the young men, who "do not ask" and "do not know" of the woman's presence among them. ${ }^{19}$ Fouissance is also linked to the idea of giving in the féminine libidinal economy-one gives not to receive, but to "give for," as Cixous notes:

She too, with open hands, gives herself-pleasure, happiness, increased value, enhanced self-image. But she doesn't try to 'recover her expenses.' She is able not to return to herself, never settling down, pouring out, going everywhere to the other. She does not flee extremes; she is not the being-of-the-end (the goal), but she is how-far-being-reaches. $(N B W, 87)$

Because "being" is extended beyond conventional gender identity in section eleven of Song of Myself, both the woman and the speaker of the poem go "everywhere to the other," reaching beyond the walls and windows of the woman's home. Instead of ending with the woman recognizing that she is still in her room (the closure of the fantasy), the passage ends instead (and more evocatively) as if she had joined them. Woman's repressed desire is revealed through absence and concealment. Going beyond the window precipitates the woman's ability to experience a fantasied sexual union with the young men, and through her, the poem's speaker, too, experiences this fantasy, writing out his own 
homoerotic desire as well as the woman's autoerotic desire.

In the latter part of the first section of "The Sleepers," Whitman writes out another fantasy, the night-time fantasy of a sleeping woman. Prior to this autoerotic sequence in the poem, the "I" speaker "sleep[s] close with the other sleepers each in turn" (29), but none of the dreams of these "other sleepers" is rendered so explicitly as that of the woman who awaits her "truant lover" (47). Being with the other in darkness and dream allows Whitman to express a way of knowing outside conventional discourse. This féminine way of knowing modifies the "relation to the other" as well as adds the "experience of the body." In the darkness all desires mingle, all bodies recline and slumber:

The female that loves unrequited sleeps,

And the male that loves unrequited sleeps,

The head of the money-maker that plotted all day sleeps,

And the enraged and treacherous dispositions, all, all sleep. (19-22)

The darkness Whitman enters into in "The Sleepers" represents repressed libidinal urges. By writing out these unvoiced desires, Whitman creates an écriture linked to the body.

In this passage Whitman uses the "I" subject pronoun in writing from the position of the sleeping woman, which allows for the gradual revelation of the woman's emotions as she reaches sexual climax. "I am she who adorn'd herself and folded her hair expectantly, / My truant lover has come, and it is dark" (46). This line sets the scene for the intimate, erotic sequence which follows. The notion of truancy expands as the passage unfolds, for in the description which follows we learn that it is the woman who is "truant" - not her lover, who has reached orgasm and slumbers next to her:

Double yourself and receive me darkness,

Receive me and my lover too, he will not let me go without him.

I roll myself upon you as upon a bed, I resign myself to the dusk.

He whom I call answers me and takes the place of my lover,

He rises with me silently from the bed.

Darkness, you are gentler than my lover, his flesh was sweaty and panting,

I feel the hot moisture yet that he left me.

My hands are spread forth, I pass them in all directions,

I would sound up the shadowy shore to which you are journeying.

Be careful darkness! already what was it touch'd me?

I thought my lover had gone, else darkness and he are one,

I hear the heart-beat, I follow, I fade away. (48-59)

Literally, it is not "darkness" but the woman's own hands which appear to be the agent of touch she queries in line fifty-seven. The passage is 
written in an unusual series of couplets and triplets uncharacteristic of Whitman, whose lines for the most part fall into loose stanzas and long, uneven catalogues. This grouping of lines allows for a series of rhythmic segues between the initial portrait of the woman folding "her hair expectantly," waiting for her "truant lover," her invitation to the darkness, the description of the lover who sleeps quietly beside her, and the love-making scene. The passage catalogues a gradual shift of desire on the woman's part away from the lover with whom she sleeps toward the darkness, then a return to her lover, who she wants to include as well.

The gift the woman offers is herself as well as her lover. The woman asks the darkness to "receive" her and her lover. Together, the two assume the masculine role and the darkness is asked to assume the feminine role of reception, although the poem genders the response from the dark as masculine, "He whom I call" from the dark to "Double yourself." Speaking metaphorically of the féminine libidinal economy, Cixous describes the woman who opens herself up to expansion as coming "out of herself to go to the other, a traveler in unexplored places; she does not refuse, she approaches, not to do away with the space between, but to see it, to experience what she is not, what she is, what she can be" (NBW, 86). In this passage from "The Sleepers," Whitman as well as the sleeping woman whose fantasy he describes goes "out to the other," in order to express repressed desire, as the following line attests: "I roll myself upon you as upon a bed, I resign myself to the dusk" (50).

Howard J. Waskow interprets this passage as made up of alternating gender roles: "First the voice expresses male agressiveness . . . then female passivity; the darkness, conversely, is first the passive party, then the active party, while being at the same time what it has been from the start of the episode-the place of love, the setting for the love affairs of both hero and woman." ${ }^{20}$ M. J. Killingsworth, on the other hand, notes that the speaker "emerges in a passive, female role" in this section of the poem (Poetry of the Body, 19). As in section five of "Song of Myself," however, gender constructs dissolve and distinctions between male/ female and active/passive disappear. Indeed, the woman becomes, in a sense, bisexual, just as the darkness is "Double." That is, she allows the "other" to come through in her expression of desire. To use Cixousian terms, she opens up to the "location within oneself of the presence of both sexes, evident and insistent in different ways according to the individual, the nonexclusion of difference or of a sex, and starting with this 'permission' one gives oneself, the multiplication of the effects of desire's inscription on every part of the body and the other body" $(N B W, 85)$. This bisexuality is not androgynous, for androgyny posits an asexual unity in which two halves are brought together and a "fantasy of unity" (NBW, 84$)$ is superimposed. Indeed, androgyny simply posits 
union and wholeness because of the commingling of sexual characteristics; the other bisexuality which Cixous describes represents an opening of the self, whether male or female, to difference, to féminine and masculine libidinal energies within.

In "The Sleepers," the darkness matches the woman's desires as the lover could not. "He will not let me go without him," the woman tells the darkness, in reference to her lover. Departure and separation in this instance are not allowed as leave-taking in an orgasmic sense becomes restricted. A féminine libidinal economy, however, as Cixous notes, "is an economy which has a relation to property that is more supple, that can stand separation and detachment which signifies that it can also stand freedom, for example the other's freedom."21 When the woman rises silently from the bed, she leaves her lover behind. The darkness hears her unvoiced desire, and becomes a substitute for the lover who slumbers quietly. "He whom I call answers me and takes the place of my lover, / He rises with me silently from the bed" (51-52). Indeed, the woman and her lover have just made love, yet she, perhaps, has not reached orgasm, or if so, has not exhausted her potential for orgasm, for jouissance, for giving without being spent: "he will not let me go without him" (49). Near climax, the woman asks the darkness not to be as careless and ungentle, as binding and restricting, as her lover. In sleep and in dreams, the woman is released from the restrictions of the "he." As "he" sleeps, identities merge in the dream logic of the deeper psyche, but then darkness and the lover merge, and the woman thinks of the one she left behind, sleeping in their bed. The coming together of woman, lover, and darkness is compressed to three lines: "Be careful darkness! already what was it touch'd me? / I thought my lover had gone, else darkness and he are one, / I hear the heart-beat, I follow, I fade away" (57-59). In line fifty-seven, the woman asks the darkness to be gentle, "careful" in the love-making which is to follow; careful as her ungentle lover was not. Touch calls forth a recognition of the darkness - "already" - the moment of climax has come. "I thought" in line fifty-eight refers to the woman's uncertainty about this "other" who embraces her: perhaps it is her lover and not the darkness, perhaps the darkness is her lover, perhaps it is neither. The last line renders the love-making sequence directly; the woman hears "the heart-beat" (whose? her own? the lover's? the darkness's? the other's?), follows, fades away. "He whom I call answers me," the woman says earlier (51); this "other" answers through a voicing and a sharing of libidinal desire. The erotic subject of this passage momentarily passes into the other. Night and she and her lover become one, and they fade together in the last line's collapse of centered subjectivity as the "I" "fade[s] away."

In this segment of "The Sleepers," hands and touch become harbingers of openness and orgasmic joy: "My hands are spread forth, I 
pass them in all directions" the woman dreams, "I would sound up the shadowy shore to which you are journeying" (55-56). The open hand, fingers fully extended, signifies how the woman has opened herself to the body and touch of her lover darkness. ${ }^{22}$ In contrast to the single, "closed act" which the woman's sleeping lover seems to have accomplished, her desire keeps going. "If she is a whole, it's a whole composed of parts that are wholes, not simple partial objects but a moving, limitlessly changing ensemble, a cosmos tirelessly traversed by Eros, an immense astral space not organized around any one sun that's any more of a star than the other," Cixous writes, of the "wonder of being several" ("Medusa," 889). The autoerotic fantasy Whitman writes out in this passage becomes an expression of the "flying in language and making it fly" ("Medusa," 887) which the French writers emphasize. In "Crossing Brooklyn Ferry," Whitman figures the text as the living, sentient link between beings separated by time and space. The Leaves as body/text become the hand fully extended, a touch which serves as the fleshly link between the reader and poet. This segment of "The Sleepers" and section eleven of "Song of Myself" startlingly write out woman's body and woman's desire, serving as exemplary instances of l'écriture féminine.

Saint Xavier University

\section{NOTES}

1 Walt Whitman, as cited in Horace Traubel's With Walt Whitman in Camden (New York: Appleton, 1908), 2:331.

2 See, for instance, Harold Aspiz, "Walt Whitman: The Spermatic Imagination," American Literature 56 (1984), 379-395, and M. J. Killingsworth, "Whitman's Sexual Themes During a Decade of Revision: 1866-1876," Walt Whitman Quarterly Review 4 (1986): 7-15. In regard to the theme of male homosexuality as encoded in the Leaves, see Roger Asselineau, The Evolution of Walt Whitman: The Creation of a Book (Cambridge, Massachusetts: Harvard University Press, 1962), 2:108-128; Robert K. Martin, The Homosexual Tradition in American Poetry (Austin: University of Texas Press, 1979); Alan Helms, "Hints . . . Faint Clews and Indirections': Whitman's Homosexual Disguises," in Walt Whitman Here and Now, ed. Joann P. Krieg (Westport, Conn.: Greenwood Press, 1985), 61-67; and Michael Moon's Disseminating Whitman: Revision and Corporeality in Leaves of Grass (Cambridge: Harvard University Press, 1991). This is by no means an exhaustive survey of studies of sexuality in Whitman's verse; however, these works do touch upon the major issues in Whitman scholarship in regard to male sexuality in Leaves of Grass.

3 Walt Whitman, Leaves of Grass: A Textual Variorum of the Printed Poems, ed. Sculley Bradley, Harold W. Blodgett, Arthur Golden, William White (New York: New York University Press, 1980), 1:26-27, lines 425-426. Subsequent references to Leaves of Grass are to this edition and will be cited parenthetically in the text by line number.

4 For considerations of Whitman's ideas about motherhood, see Arthur Wrobel, "Noble American Motherhood: Whitman, Women, and the Ideal Democracy," American 
Studies 21 (1980), 7-25, and Myrth Jimmie Killingsworth, "Whitman and Motherhood: A Historical View," American Literature 54 (1982), 28-43. Other studies point to the inconsistency of Whitman's attitudes about women. Nina Baym finds Whitman's attempts to portray women as equals "inconsistent and unconvincing." See her essay, "Portrayal of Woman in American Literature, 1790-1870," in What Manner of Woman: Essays on English and American Life and Literature, ed. Marlene Springer (New York: New York University Press, 1977), 211-234. See also Kay F. Reinartz, "Walt Whitman and Feminism," Walt Whitman Review 19 (1973), 127-137. Michael Moon discusses lesbian desire in section six of "The Sleepers" in the second chapter of his book, Disseminating Whitman. See also Karen Oakes, “I stop somewhere waiting for you': Whitman's Femininity and the Reader of Leaves of Grass" in Out of Bounds: Male Writers and Gender(ed) Criticism (Amherst: University of Massachusetts Press, 1990), 169-185. Using Nancy Chodorow's theories about the construction of "masculine" and "feminine," Oakes's discussion centers around Whitman's "repressed feminine voice" (181).

5 For an introduction to the ways in which Cixous's approach to reading can enhance teaching, see The Body and The Text: Hélène Cixous, Reading and Teaching, eds. Helen Wilcox, Keith McWatters, et al. (New York: St. Martin's Press, 1990).

6 In her essay, "The Laugh of the Medusa," Cixous encourages the expression of psychic sexual experiences, which she calls writing woman's body: "Write! and your self-seeking text will know itself better than flesh and blood, rising, insurrectionary dough kneading itself, with sonorous, perfumed ingredients, a lively combination of flying colors, leaves, and rivers plunging into the sea we feed. . . . But look, our seas are what we make of them, full of fish or not, opaque or transparent, red or black, high or smooth, narrow or bankless; and we are ourselves sea, sand, coral, seaweed, beaches, tides, swimmer, children, waves. . . . More or less wavily sea, earth, sky - what matter would rebuff us? We know how to speak them all." (Trans. Keith Cohen and Paula Cohen, in Signs: Fournal of Women in Culture and Society [1976], 884).

7 "Cosmic Consciousness," in Start With the Sun: Studies in the Whitman Tradition (Nebraska: University of Nebraska Press, 1960), 30.

8 Cixous has been critiqued for this emphasis on the female body and on the nonrational, intuitive approach to knowing; some feminist critics view this approach as essentialist. For a discussion of these issues, see Revaluing French Feminism: Critical Essays on Difference, Agency, and Culture, ed. Nancy Fraser and Sandra Lee Bartky (Bloomington: Indiana University Press, 1992).

9 "Reaching the Point of Wheat, or a Portrait of the Artist as a Maturing Woman," New Literary History 19 (1987), 19.

10 Most readings of "Crossing Brooklyn Ferry" focus upon Whitman's cataloging of rivers, horizon, and self. Stephen Black sees the poem as most successful when Whitman attains a coordination between "inner topography" and the landscape (Whitman's fourneys Into Chaos: A Psychological Study of the Poetic Process [Princeton: Princeton University Press, 1975]). Betsy Erkkila views the speaker's fragmentation as indicative of the political upheaval and uncertainty in America during the 1850s (Whitman the Political Poet [New York: Oxford University Press, 1989]). And Michael Moon focuses particularly on the 1856 text of the poem as an exploration of "certain difficult questions of desire, especially the dynamics of oedipalized desire" (Disseminating Whitman, 107).

11 "Castration or Decapitation?" trans. Annette Kuhn, Signs: fournal of Women in Culture and Society (1981), 53. 
12 Notebooks and Unpublished Prose Manuscripts, ed. Edward F. Grier (New York: New York University Press, 1984), 1:95.

13 In Writing Differences: Readings from the Seminar of Hélène Cixous, ed. Susan Sellers (New York: St. Martin's Press, 1988), 23.

14 Whitman's Drama of Consensus (Chicago: University of Chicago Press, 1988), 8 (my emphasis).

15 Prose Works 1892, ed. Floyd Stovall (New York: New York University Press, 1964), 2:725.

16 The Newly Born Woman, trans. Betsy Wing (Minneapolis: University of Minneapolis Press, 1986), 85-86. Subsequent references to this text will be cited parenthetically as $N B W$.

17 See, for instance, Emilio De Grazia, "More on Whitman's 28 Young Men," Walt Whitman Review 21 (1975), 158-160; Pamela Postma, "Self-Marriage, Dream-Children, and the Poetic Imagination: A New Reading of Whitman's 'Twenty-eight Young Men,"' American Transcendental Quarterly 61 (1986), 37-45; Harold Aspiz, Walt Whitman and the Body Beautiful (Urbana: University of Illinois Press, 1980); and M. Jimmie Killingsworth, Whitman's Poetry of the Body: Sexuality, Politics, and the Text (Chapel Hill: University of North Carolina Press, 1989).

18 Fouissance, perhaps untranslatable, signifies one of the aims of féminine discourse: a liberation and a voicing of desire. Leon S. Roudiez, in his "Introduction" to Julia Kriesteva's Desire in Language (New York: Columbia University Press, 1980) traces the meaning given the word to Jacques Lacan's 1972-1973 seminar. "What is significant," Roudiez writes, "is the totality of enjoyment that is covered by the word 'jouissance' both in common usage and in Lacan ... 'jouissance' is sexual, spiritual, physical, conceptual at one and the same time" (16).

19 In "The Laugh of the Medusa" Cixous writes, "Men still have everything to say about their sexuality, and everything to write. For what they have said so far, for the most part, stems from the opposition activity / passivity, from the power relation. . . . The way man has of getting out of himself and into her whom he takes not for the other but for his own, deprives him, he knows, of his own bodily territory" "Medusa," note $1,877)$. Despite the many studies of Whitman's male sexual "economy," much is still left to be written. For a discussion of the ways in which Whitman's "trope of a male 'body electric"' is grounded in nineteenth-century scientific thought, see Harold Aspiz, Walt Whitman and the Body Beautiful (Urbana: University of Illinois Press, 1980), 145-148.

20 Whitman: Explorations in Form (Chicago: University of Chicago Press, 1966), 146.

21 "voice i . . . hélène cixous and verena andermatt conley," Boundary 2 (1984), 57.

22 See E. H. Miller, Walt Whitman's Poetry: A Psychological fourney (New York: New York University Press, 1968), 74, for a discussion of the hand in Whitman's Leaves. 